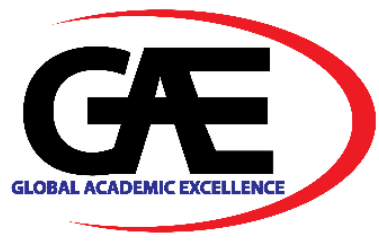

\title{
MOBILE APPLICATIONS DEVELOPED BY ARAB COUNTRIES IN RESPONSE TO COVID-19: A REVIEW
}

\author{
Zainab Hameed Alfayez ${ }^{1 *}$, Nabaa Mohammed Al-Sinayyid ${ }^{2}$, Sadeq Ibrahim AL-Ameri ${ }^{3}$
}

1 Computer Information System, Computer Science\& Information Technology, University of Basrah, Basrah, Iraq Email: zainab.meejeed@uobasrah.edu.iq

2 Computer Science\& Information Technology, University of Basrah, Basrah, Iraq Country

Email: nabaa.abdulkareem96@gmail.com

3 Computer Science\& Information Technology, University of Basrah, Basrah, Iraq Country

Email: Sadiq1997ibrahim@gmail.com

* Corresponding Author

\section{Article Info:}

\section{Article history:}

Received date: 25.08 .2021

Revised date: 15.09 .2021

Accepted date: 25.09 .2021

Published date: 30.09 .2021

\section{To cite this document:}

Alfayez, Z. H., Al-Sinayyid, N. M., \& AL-Ameri, S. I. (2021). Mobile Applications Developed By Arab Countries In Response To Covid-19: A Review. Journal of Information System and Technology Management, 6 (22), 200-211.

DOI: $10.35631 /$ JISTM.622016

This work is licensed under $\underline{\mathrm{CC} B Y}$ 4.0

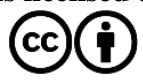

\begin{abstract}
:
Arab countries have taken different strategies in response to the COVID-19 pandemic such as: imposing travel restrictions, hygienic practices, quarantine, and a complete lock-down. They also have adopted technology-based strategies to deal with the pandemic. Mobile applications were one of these strategies since they offer an opportunity for remote communication in which potentially tackling the pandemic. Therefore, like other countries, Arab countries have developed a number of mobile apps specially to stop or mitigate the spread of the new disease. This paper aims to provide a comprehensive overview of mobile applications being developed in response to the COVID19 pandemic and especially to serve the Arab region. To achieve this goal, firstly, the related applications were chosen through searching in the two main mobile app stores (Google Play and App Store), Secondly, the number of applications developed by each country was identified, thirdly, exploring the apps in terms of the services being provided by each app. The significant findings of this review are: UAE was the Arab country that developed the biggest number of COVID-19 related mobile apps, and "remote assistant" was the service that was found in most of the identified applications. However, these applications did not consider the privacy issue and lacked solutions for healthcare staff.
\end{abstract}

Keywords:

COVID-19, Mobile Applications, Mobile Apps, Arab Region, Arab Countries 


\section{Introduction}

COVID-19 is a new disease that first explored in December 2019 in Wuhan, China. It has quickly spread across the world, prompting the WHO to announce a "pandemic" on 11 March, 2020 (WHO Director-General's Opening Remarks at the Media Briefing on COVID-19, 2020). In the Arab region ${ }^{1}$, the first confirmed case was announced in the United Arab Emirates on 29 January 2020 (Turak, 2020). Since then, number of confirmed cases were found in other countries. As On 9 April 2020, all countries in the Arab region have reported COVID-19 cases (Anonymous, 2020).

Like other world governments, Arabic authorities have taken several urgent policies to tackle the rapid spread of the new virus such as: travel restrictions, stay-at-home orders, school and business closures, social gathering bans (Hasan, 2021), quarantine for those who are suspected of being sick, adherence to sanitary procedures (often hand washing, wearing a face mask) (Singhal, 2020), and even a complete lock-down (HM Coastguard Asks Everyone to Take Extra Care, 2020). Aside from these plans, information and communication technology-based strategies played an essential role during the pandemic. Technologies like mobile applications, web applications, online dashboards, and electronic gadgets have been adopted by many countries (including Arab countries) to raise awareness of how to response and cope with the breakout of COVID-19 (ISLAM et al., 2020).

One of the earliest responses options to COVID-19 pandemic was developing mobile apps that are dedicated to fight the new disease. Mobile applications have the features of availability, acceptability, and simple to use. They uniquely provide an opportunity for remote communication, which aids in social distancing (Nayak et al., 2016). As a result of these features, Arabic health organizations and governments have developed a variety of mobile applications to combat the novel virus. For example, Qatar has developed coronavirus contact tracking app called "Ehteraz" which allows the government to track if users have been in close contact with an infected person (Najib, 2021), while KSA provided teleconsultation in its "Sehha" app through integrating live video chat and SMS text messaging into it (Hassounah et al., 2020).

The present study is aimed to give a comprehensive overview on mobile applications being developed in response to COVID-19 pandemic. In more specifically the apps being developed to serve the Arab world. the study attempts to answer two questions: RQ1: How many apps were developed by each Arab country? RQ2: What are the services provided by each app? The goals of this review were to: (i) search in the two main mobile app stores (Google play and App Store) to find mobile applications being developed by Arab countries in response to COVID19 , (ii) identify the number of applications developed by each country, (iii) explore the apps in terms of the services being provided by each app.

\section{Methodology}

The review followed PRISMA (Preferred Reporting Items for Systematic Reviews and MetaAnalyses) guidelines (Liberati et al., 2009). It examines mobile applications related to the COVID-19 pandemic, with a focus on those created to support the Arab communities. The below sections discussed the steps which were followed to conduct the review:

\footnotetext{
${ }^{1}$ Arab area consists of 22 counties which are: Algeria, Bahrain, Comoros, Djibouti, Egypt, Iraq, Jordan, Kuwait, Lebanon, Libya, Mauritania, Morocco, Oman, Palestine, Qatar, the Kingdom of Saudi Arabia, Somalia, Sudan, Syria, Tunisia, the United Arab Emirates, and Yemen. 


\section{Data Collection}

The data of this review were collected from two main mobile applications stores: Android Google Play and Apple Store. The data collection was conducted on $1^{\text {st }}$ of April 2021. Each store was searched to find the relevant applications. The search involved two languages English and Arabic using the following keywords: "COVID-19", "corona", "coronavirus", "pandemic",

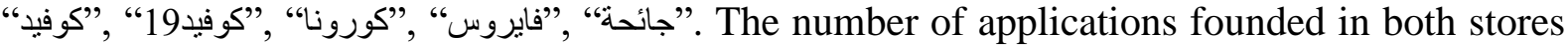
were $\mathrm{N}=476$. However, the number declined to $\mathrm{N}=283$ after extracting the applications that are not related to COVID-19. This extraction was done through scanning the apps' names, descriptions, and their screenshots. A second round of exclusion was executed to extract the apps which were not developed to specifically to serve Arab region. The total number of extracted apps was $\mathrm{N}=228$, which mains the number of the remained apps $\mathrm{N}=55$. The final round of exclusion criteria was done through removing duplicated apps which were existed in both stores. The final number of identified applications was $\mathrm{N}=30$. These apps were downloaded, analysed, and mapped according to the service they provide. Figure 1 . shows the data collection method with exclusions criteria.

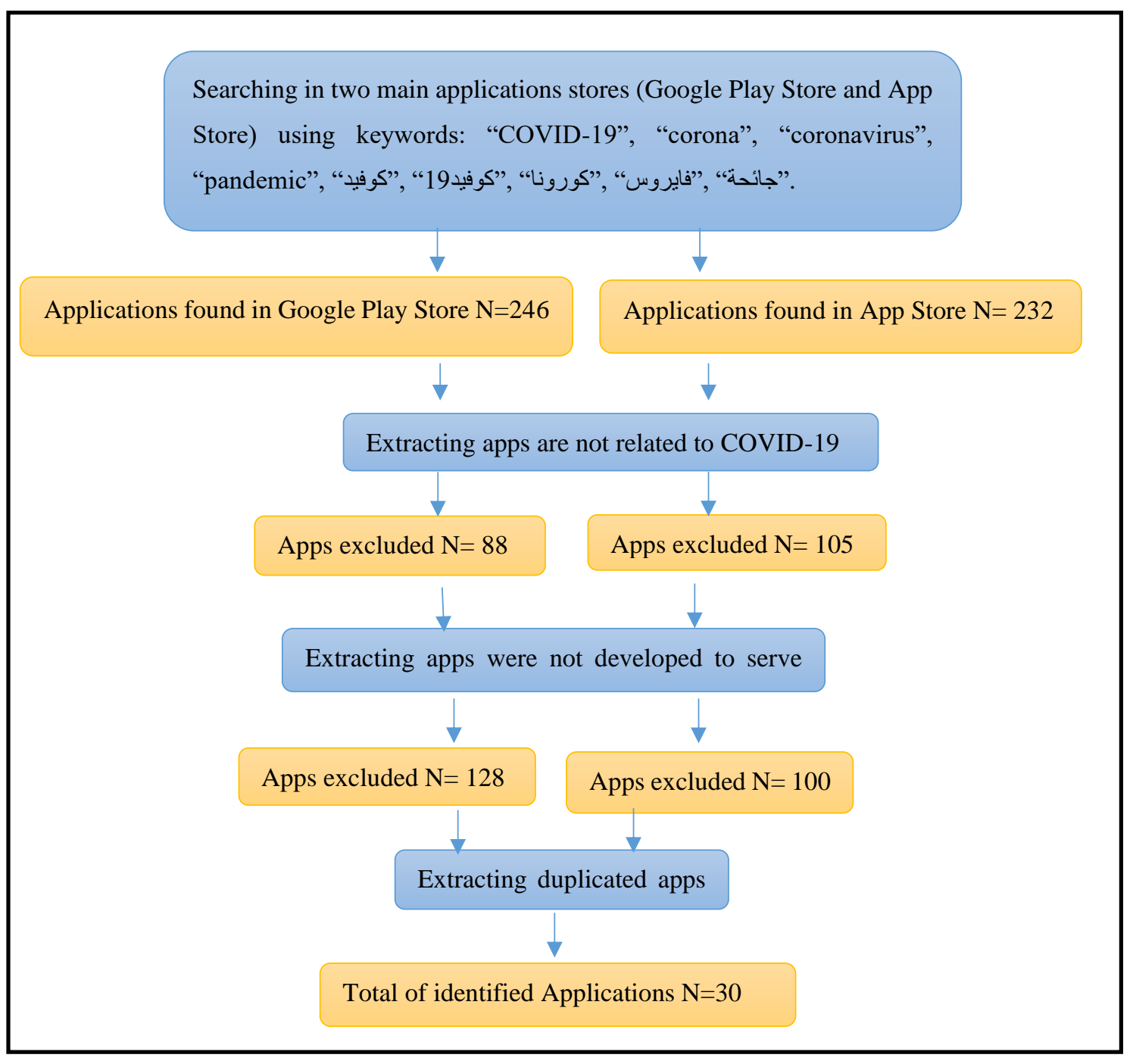

Figure 1: Flow Chart Of The Review Methodology And The Inclusion And Exclusion Process. 


\section{Data Mapping}

A total of 30 Applications were identified. These applications were screened and analyzed. Firstly, the authors identified the country that developed each application (RQ.1). Beside countries, the authors determined general details about each application such as: the application language, the users rating, the cost of downloading, and the application platform. Two of the authors worked separately on this process. After that, they compared their findings. If they had opposing viewpoints, a debate was conducted to find a consensus. The general information of each app was mostly obtained by reading "about this app" section and browsing its screens without downloading the app on the device. Table (1) shows the details of the applications found in Android Google Play and App Store related to COVID-19 and developed to serve Arab region.

The next task was to determine the services provided by each application (RQ2). The majority of the services were identified after downloading the app and using it in order to explore its features. Similar services were grouped and clustered into categories and subcategories likewise the approach used in (ISLAM et al., 2020). Table (2) shows the services provided by each application.

Table 1: The Details of The Applications Related to COVID-19 That Developed to Serve Arab Region.

\begin{tabular}{|c|c|c|c|c|c|c|c|}
\hline $\begin{array}{l}\text { App } \\
\text { NO. }\end{array}$ & App Name & $\begin{array}{l}\text { Star } \\
\text { Rating }\end{array}$ & download & Cost & Platform & Country & Language \\
\hline App1 & Wiqaytna & 4.2 & $1 \mathrm{M}+$ & Free & $\begin{array}{l}\text { Android+ } \\
\text { IOS }\end{array}$ & Morocco & Arabic+ French \\
\hline App2 & $\begin{array}{l}\text { Tabaud(COVID- } \\
19 \text { KSA) }\end{array}$ & 4.5 & $1 \mathrm{M}+$ & Free & $\begin{array}{l}\text { Android+ } \\
\text { IOS }\end{array}$ & KSA & Several \\
\hline App3 & $\begin{array}{l}\text { COVID19-DXB } \\
\text { Smart App }\end{array}$ & 2.6 & $500 \mathrm{~K}$ & Free & $\begin{array}{l}\text { Android+ } \\
\text { IOS }\end{array}$ & UAE & Arabic+ English \\
\hline App4 & Covid19 UAE & 4.3 & $50 \mathrm{~K}+$ & Free & $\begin{array}{l}\text { Android+ } \\
\text { IOS }\end{array}$ & UAE & Arabic+English+Urdu \\
\hline App5 & اطمن-حمياتك كورنا & 4.7 & $10 \mathrm{~K}+$ & Free & Android & Egypt & Arabic \\
\hline App6 & صحة مصر & 3.3 & $1 \mathrm{M}+$ & Free & $\begin{array}{l}\text { Android+ } \\
\text { IOS }\end{array}$ & Egypt & Arabic+ English \\
\hline App7 & Tarassud+ & 3.6 & $100 \mathrm{k}+$ & Free & $\begin{array}{l}\text { Android } \\
+\mathrm{IOS}\end{array}$ & Oman & Arabic + English \\
\hline App8 & Tawakkalna & 4.5 & $10 \mathrm{M}+$ & Free & $\begin{array}{l}\text { Android } \\
+\mathrm{IOS}\end{array}$ & $\mathrm{KSA}$ & several \\
\hline App9 & COVID19- Libya & 4.2 & $10 \mathrm{~K}+$ & Free & Android & Libya & Arabic + English \\
\hline App10 & Tetamman & 3.7 & $1 \mathrm{M}+$ & Free & $\begin{array}{l}\text { Android } \\
+\mathrm{IOS}\end{array}$ & KSA & Arabic + English \\
\hline App11 & EgyptCare & 4.5 & $1 \mathrm{~K}+$ & Free & Android & Egypt & Arabic \\
\hline App12 & COVI & 4.4 & $100 \mathrm{~K}+$ & Free & $\begin{array}{l}\text { Android } \\
+\mathrm{IOS}\end{array}$ & Qatar & Several \\
\hline App13 & Ma3an & 2.5 & $50 \mathrm{~K}+$ & Free & $\begin{array}{l}\text { Android+ } \\
\text { IOS }\end{array}$ & Lebanon & Arabic + English \\
\hline
\end{tabular}


Volume 6 Issue 22 (September 2021) PP. 200-211

DOI: 10.35631/JISTM.622016

\begin{tabular}{|c|c|c|c|c|c|c|c|}
\hline App14 & CoronaSAFE & 4.4 & $1 \mathrm{~K}+$ & Free & $\begin{array}{l}\text { Android+ } \\
\text { IOS }\end{array}$ & Sudan & Arabic + English \\
\hline App15 & BeAware Bahrain & 4.7 & $500 \mathrm{~K}+$ & Free & $\begin{array}{l}\text { Android+ } \\
\text { IOS }\end{array}$ & Bahrain & Several \\
\hline App16 & AMAN & 3.2 & $1 \mathrm{M}+$ & Free & $\begin{array}{l}\text { Android+ } \\
\text { IOS }\end{array}$ & Jordan & Arabic + English \\
\hline App17 & $\begin{array}{c}\text { CORONAVIRUS } \\
\text { ALGÉRIE }\end{array}$ & 2.7 & $100 \mathrm{k}+$ & Free & $\begin{array}{l}\text { Android+ } \\
\text { IOS }\end{array}$ & Algeria & Arabic + French \\
\hline App18 & SEHA & 3.7 & $500 \mathrm{~K}+$ & Free & $\begin{array}{l}\text { Android+ } \\
\text { IOS }\end{array}$ & UAE & Arabic + English \\
\hline App19 & ALHOSN UAE & 3.7 & $1 \mathrm{M}+$ & Free & $\begin{array}{l}\text { Android+ } \\
\text { IOS }\end{array}$ & UAE & Arabic + English \\
\hline App20 & Shlonik & 4.0 & $100 \mathrm{~K}+$ & Free & $\begin{array}{l}\text { Android+ } \\
\text { IOS }\end{array}$ & Kuwait & Several \\
\hline App21 & $\mathrm{E} 7 \mathrm{mi}$ & 3.6 & $50 \mathrm{~K}+$ & Free & $\begin{array}{l}\text { Android+ } \\
\text { IOS }\end{array}$ & Tunisia & Arabic + French \\
\hline App22 & Ehteraz & 4.2 & $1 \mathrm{M}$ & Free & $\begin{array}{l}\text { Android+ } \\
\text { IOS }\end{array}$ & Qatar & Arabic + English \\
\hline App23 & Stay Home UAE & 4.0 & $1 \mathrm{~K}+$ & Free & $\begin{array}{l}\text { Android+ } \\
\text { IOS }\end{array}$ & UAE & $\begin{array}{l}\text { Arabic+English+ } \\
\text { Hindi }\end{array}$ \\
\hline App24 & Reaya UAE & 2.9 & $1 \mathrm{k}+$ & Free & $\begin{array}{l}\text { Android+ } \\
\text { IOS }\end{array}$ & UAE & Several \\
\hline App25 & Cradar & 2.5 & $10 \mathrm{k}+$ & Free & $\begin{array}{l}\text { Android+ } \\
\text { IOS }\end{array}$ & Jordan & Arabic + English \\
\hline App26 & Sehtak & 4.2 & $50 \mathrm{~K}+$ & Free & $\begin{array}{l}\text { Android+ } \\
\text { IOS }\end{array}$ & Jordan & Arabic + English \\
\hline App27 & Sehatty & 4.3 & $100 \mathrm{~K}+$ & Free & $\begin{array}{l}\text { Android+ } \\
\text { IOS }\end{array}$ & Palestine & Arabic + English \\
\hline App28 & Sehhaty & 4.5 & $5 \mathrm{M}+$ & Free & $\begin{array}{l}\text { Android+ } \\
\text { IOS }\end{array}$ & KSA & Arabic + English \\
\hline App29 & PH Screening & 4.2 & $100 \mathrm{~K}+$ & Free & $\begin{array}{l}\text { Android+ } \\
\text { IOS }\end{array}$ & UAE & Arabic + English \\
\hline App30 & Immune & 4.5 & $1 \mathrm{M}+$ & Free & Android+IOS & Kuwait & Arabic + English \\
\hline
\end{tabular}


Table 2: The Services Provided By Each Application.

\begin{tabular}{|c|c|c|}
\hline Service & Details & Mobile apps \\
\hline \multirow{5}{*}{$\begin{array}{l}\text { Remote } \\
\text { assistance } \\
26 \text { app }\end{array}$} & $\begin{array}{l}\text { Videos/ call } \\
\text { consultation }\end{array}$ & $\begin{array}{l}\text { COVID19-DXB Smart App, COVID19 UAE, صحة, Sehhaty, Be Aware Bahrain, SEHA, Shlonik, } \\
\text { Tawakkalna (COVID19-KSA) } \\
\text { Tawakalna }\end{array}$ \\
\hline & instant messaging & $\begin{array}{l}\text { Ma3an, AMAN, Tarassud+, EgyptCare, COVID19- } \\
\text { DXB Smart App, Sehatty }\end{array}$ \\
\hline & emergency call & $\begin{array}{l}\text { Tabaud(COVID-19 KSA), COVID19-DXB Smart App, } \\
\text { صحة مصر, Tetamman, BeAware Bahrain, Ma3an, } \\
\text { Ehteraz, AMAN }\end{array}$ \\
\hline & Self- assessment & $\begin{array}{l}\text { Tetamman, COVI, Coronaviruse Algerie, } \\
\text { CoronaSAFE, Sehhaty, SEHA, Tarassud+, E7im, } \\
\text { Reaya UAE, Stay Home UAE, PH Screening }\end{array}$ \\
\hline & $\begin{array}{l}\text { Warning notification } \\
\text { related to new } \\
\text { affected geographical } \\
\text { regions }\end{array}$ & $\begin{array}{l}\text { Wiqaytna, COVID19-DXB Smart App, صحة مصر, } \\
\text { Tetamman, BeAware Bahrain, Coronaviruse Algerie, } \\
\text { Ma3an, AMAN, Covid19-Libya, Tawakkalna, Ehteraz, } \\
\text { E7mi }\end{array}$ \\
\hline $\begin{array}{l}\text { Monitor } \\
\text { patients }\end{array}$ & $\begin{array}{l}\text { observing the users' } \\
\text { health parameters } \\
\text { such as temperature, } \\
\text { heart rate, oxygen, } \\
\text { and blood pressure. }\end{array}$ & Shlonik, SEHA \\
\hline $\begin{array}{l}\text { Current } \\
\text { status }\end{array}$ & $\begin{array}{l}\text { Statistics (the number } \\
\text { of new cases, } \\
\text { recovery and death) }\end{array}$ & $\begin{array}{l}\text { Wiqaytna, Tabaud(COVID-19 KSA), COVID19-DXB } \\
\text { Smart App, COVID19- Libya, كورونا من حمايتك - اطمن, } \\
\text { COVID19 UAE, BeAware Bahrain, EgyptCare, COVI, } \\
\text { SEHA, Shlonik, Tawakkalna(covid19-KSA), Covid19- } \\
\text { Libya, Sehtak, Tarassud+, Ehteraz, Reaya UAE, } \\
\text { Sehhaty }\end{array}$ \\
\hline \multirow{2}{*}{$\begin{array}{l}\text { Control covid- } \\
19\end{array}$} & Prevention guidance & 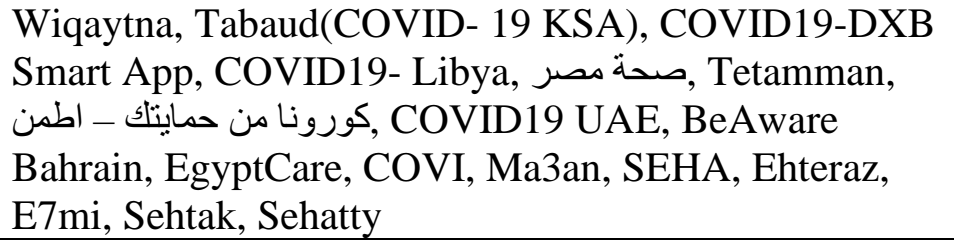 \\
\hline & $\begin{array}{l}\text { Report the suspected } \\
\text { cases to the health } \\
\text { authority }\end{array}$ & $\begin{array}{l}\text { Wiqaytna, Tabaud(COVID- } 19 \text { KSA), COVID19- } \\
\text { Libya, صحة مصر, Ma3an, Coronaviruse Algerie, } \\
\text { ALHOSN UAE, Covid-19 Libya, Cradar }\end{array}$ \\
\hline \multirow[t]{2}{*}{$\begin{array}{l}\text { Medical } \\
\text { facilitates }\end{array}$} & $\begin{array}{l}\text { search or show the } \\
\text { nearby medical } \\
\text { facilitates. }\end{array}$ & $\begin{array}{l}\text { COVID19-DXB Smart App, BeAware Bahrain, } \\
\text { Shlonik, Tetamman, Sehhaty, SEHA, Sehtak, PH } \\
\text { Screening }\end{array}$ \\
\hline & $\begin{array}{l}\text { Vaccination } \\
\text { information }\end{array}$ & ALHOSN UAE, Sehhaty, Tarassud+, Immune, \\
\hline
\end{tabular}




\section{Results}

This section reports the results obtained from reviewing and analyzing 30 applications that were found to serve Arab region during COVID-19 pandemic.

\section{RQ1: How Many Apps Were Developed Regarding Each Country?}

The review first investigation was to know the number of mobile applications were developed in regard to each Arab country. The results showed that Arab area digitally well responded to the pandemic. 15 out of 22 countries have developed at least one mobile application related to COVID-19. Additionally, some countries like: UAE, KSA, Egypt, and Jordon have developed more than one. The results revealed that UAE has the biggest number of mobile applications regarding COVID-19, as we identified 7 apps were built to support this country. Next was KSA which has developed 4 applications followed by Egypt and Jordon with 3 applications for each. Moreover, 2 applications were found to serve the citizen of Qatar, and Kuwait during the pandemic. Whereas only one mobile application was built in each of the rest of the Arab countries in response to the novel disease. These countries are: Morocco, Libya, Palestine, Oman, Lebanon, Sudan, Bahrain, Algeria, and Tunisia. On the other side, some Arab countries did not record any digital mobile based response to the COVID-19 pandemic, as we could not find any application belongs to them. These countries are: Iraq, Yemen, Syria, Somalia, Mauritania, Comoros, and Djibouti. Figure (2) illustrates the number of mobile applications belongs to each country.

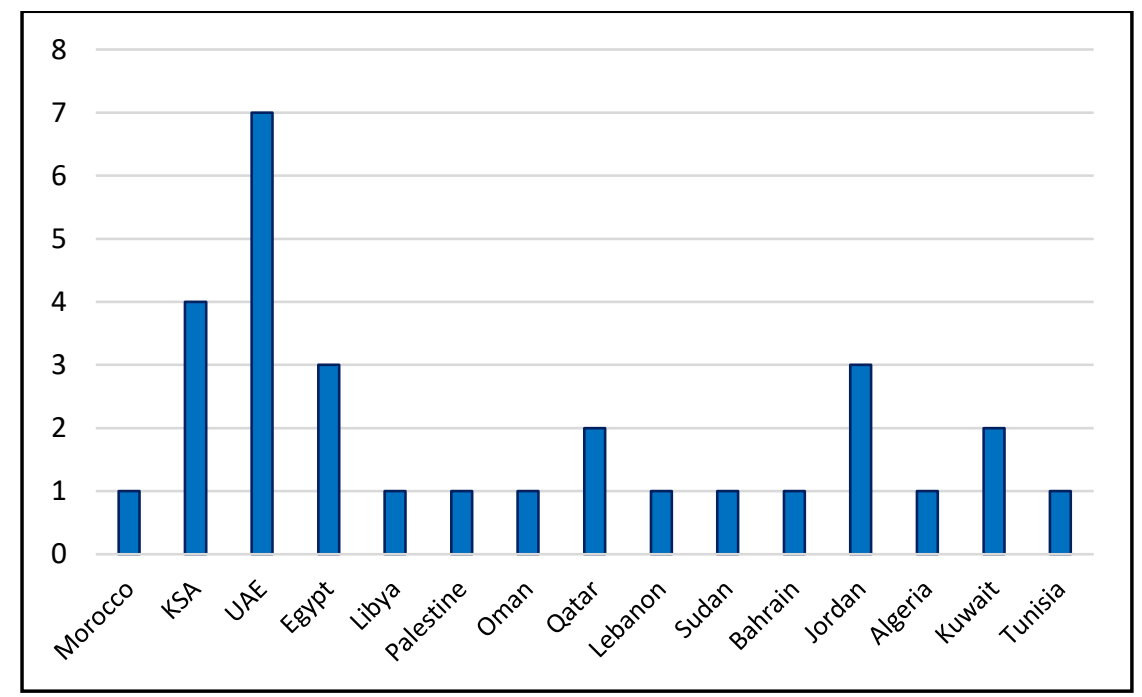

Figure 2: The Number Of COVID-19 Mobile Applications Regarding Each Country.

\section{Rq2: What Are The Services Provided By Each App?}

A total of 103 services were identified from 30 mobile applications. These services were categorized into sub-services and then clustered into 5 main services as are explained below and shown in figure (3): 


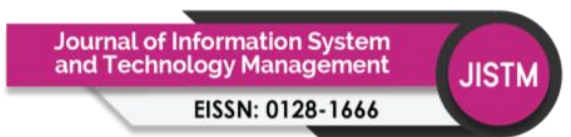

Volume 6 Issue 22 (September 2021) PP. 200-211

DOI: 10.35631/JISTM.622016

\section{Remote Assistance}

The authors found 26 out of 30 identified applications provide a remote assistance to its users. This means $86.6 \%$ of the applications provides this service. 8 apps provide remote medical consultations to its users through videos or calls to the doctors and specialists. KSA, Egypt, Bahrain, and Kuwait were the countries which integrated this service in their COVID-19 apps. However, UAE was the most interested country in video calls function, as 3 of its apps have this feature. Other countries like Jordon, Palestine, Lebanon, and Oman also provided a remote consultation service. However, they used text messaging technique. Moreover, 8 of 26 applications supports an immediate call to some of emergency telephone numbers like: ambulance, civil defense, and police office. Some of the apps, 11 out of 26 apps, deliver the service of a self-diagnose for the new disease through filling a questionnaire, where the user answers several questions related to his/her symptoms, then the app will display the results on the screen according these answers. This service was delivered by several Arab countries such as: Algeria, Qatar, Tunisia, and Sudan. Finally, some Arab countries like Morocco, Libya, KSA, and UAE have developed 12 apps to warn its users from the affected geographical regions, as the users will avoid contacting with these areas in which results in decreasing the disease spread.

\section{Monitor Patient}

Only 2 applications out of 30 intended to support COVID-19 patients. These applications were "Shlonik" developed by Kuwait, and "SEHA" developed by UAE. The two applications have included the feature of patient monitoring by tracking of the user's temperature, for example "Shlonik" app, or by other patient medical records like heart rate, oxygen levels, or blood pressure, for example "SEHA" app.

\section{Current Status}

The authors found 18 applications out of 30 were developed to inform their user with current situation and display the latest numbers of the new infections, death, and recovery. Most of the Arab countries such as: UAE, Morocco, Jordon, KSA, Libya, Egypt, and Bahrain have added this feature to their apps. Different ways were used to present the current statistics of the disease such as: representing the current figures through graphs and charts, for example," COVID19DXB Smart App", displaying the corona virus recent news by showing numbers like "BeAware Bahrain" app, or demonstrating these numbers on the country map, for example, "Tarassud+", the app that uses data visualization techniques to show Oman map and the regional statistics on it.

\section{Control COVID-19}

The analysis phase explored 26 applications that provide the service of controlling the rapid spread of the novel disease. 17 of these applications were developed to educate the users and give them a detailed information about how to avoid the infection. different methods were used to include this service into the apps. Some of them utilized a piece of video to show the instructions of COVID-19 infection prevention, while others utilized pictures and texts to explain these instructions such as: "Wiqaytna". Another way was used to control COVID-19 is to enable the user to report the suspected cases to the health authority. This service was 
included in apps like: "Wiqaytna", "Ma3an", "ALHOSN UAE", "Covid-19 Libya", and "Cradar" which were developed by Morocco, Lebanon, UAE, Libya, and Jordon respectively.

\section{Medical Facilities}

During the pandemic, several Arab countries like UAE, Bahrain, Kuwait, KSA, and Jordon have developed 12 applications that help their citizen to find the nearby medical facilities. 8 applications provide information about COVID-19 testing centers, hospitals names or hospital locations, while only 4 apps involved servers related to COVID-19 vaccination such as: vaccine locations, registration, and appointments arrangements. Additionally, some applications like "Shlonik" and "Sehhaty" show these facilities on the map along with the user current location, as this will ease the navigation process, while others like "SEHA" app offers this service by showing a list of hospitals' names with their addresses.

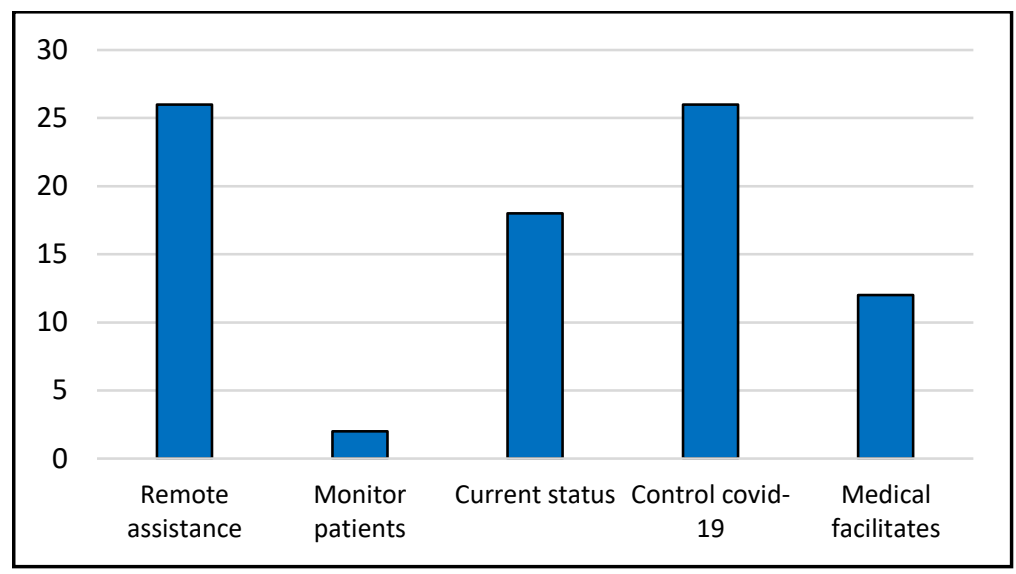

Figure 3: The Number Of COVID-19 Mobile Applications Regarding Each Service.

\section{Discussion}

This research was intended to provide a comprehensive overview on mobile application that developed to serve Arab region during the COVID-19 pandemic. The review found that Arab counties responded differently to the crises. As some Arab countries, including the UAE, KSA, Jordon, and Egypt, invested in the development of mobile applications more than others, for example, Morocco, Libya, Palestine, Oman, Lebanon, Sudan, Bahrain, Algeria, Kuwait, and Tunisia. However, several Arab countries did not take any technological actions and did not build mobile based applications to deal with pandemic, such as: Iraq, Yemen, Syria, Somalia, Mauritania, Comoros, and Djibouti.

In terms of the apps' services and functions, the review revealed that "remote assistant" and "control COVID-19" were the primary functions of the majority of the existing apps in the Arab world. With the rising number of COVID-19 instances, it is critical to build mobile apps and integrate teleconsultation options into them to ensure high-quality healthcare for all patients, including those with pre-existing diseases (Bassi et al., 2020). Arab countries had recognized the importance of telemedicine during the pandemic. As several apps had provided 
service related to teleconsultations such as: video calls, instant messages, emergency calls, questionnaires, and warning notification.

On the other side, the review found that the majority of the apps, which were developed by Arab countries, lacked features to help infected people, as only 2 of the reviewed apps provide this service. Moreover, these apps lacked functionalities that would help hospitals or healthcare staff. In contrast, other studies showed that frontline hospital people were using mobile apps to collect clinical notes and facilitate remote-monitoring features in the United States (Media, 2020).

Another interesting finding was related to the users' privacy. The study discovered that Arab countries did not consider this issue very seriously. Most of the contact tracing and monitoring apps examined in this study required user information such as name, phone number, current location, and Bluetooth interactions with other apps. Although collecting data location is necessary for mapping COVID-19 transmission hotspots, using this method may pose a threat to an individual's privacy (Alfayez, 2021). Consequently, it could present a barrier to the app acceptance and deter many from using it (Alfayez, 2021). To combat this, countries such as Singapore and Argentina are employing monitoring apps that capture only Bluetooth interaction data in order to protect user privacy (Salako \& Huet, 2020). However, Bluetooth can reach across only a few meters (Abeler et al., 2020). Therefore, some countries like Chania and United States used other technologies, for example, SMS and QR code, to fulfil the purpose of contact tracing (Cheng \& Hao, 2020), (Yasaka et al., 2020). In addition, the privacy issue affected some of COVID-19 Arabic apps rating, as some users explained in their comments. For example, a user for AMAN app gave one-star rating and commented "why this app requires access not only location but location history, photos, files and physical activities".

\section{Study Limitation}

This study had a limitation that not all COVID-19 related applications might be identified, specially the apps in Google Play Store. In order to tackle fake news and misinformation about COVID-19 disease, Google has blocked showing search results for "coronavirus", "COVID19", "كورونا" on the Play Store and play.google.com website. If the user searched for any of these terms, Google would show "no results found" message. In contrast, a search for "coronavirus", "COVID-19", "كورونا" or "كوفيد19" on Apple's App Store works normally and reveals several apps. For preventing the spread of misinformation, Apple eliminates the apps that are not from well-known organizations like governments or hospitals. In this review we tried to overcome the search limitation by changing the spelling of these terms when we were searching in Google Play Store, for example searching for "كوفيد" The " Th "كوفيد" instead of search in this way showed COVID-19 related app. Even so, we could not ensure that all apps were displayed. Moreover, beside searching on Google Play Store, we searched in App Store which shows COVID-19 apps normally. Therefore, the apps which were uploaded on both stores were identified and included in this review.

\section{Conclusion}

This review was conducted to give a detailed description of a mobile applications that were created to serve the Arab communities during the COVID-19 pandemic. The review identified 
30 mobile apps were developed to serve the Arab area. Several Arab countries such as: UAE, KSA, Jordon, and Egypt have built more than one COVID-19 related applications. In contrast, some Arab countries like Iraq, Yemen, Syria, Somalia, Mauritania, Comoros, and Djibouti have not developed a mobile application in response to the pandemic. The review results revealed that Arab countries had recognized the importance of telemedicine during the pandemic, as "remote assistant" service was provided by the most of their applications. Additionally, most of the Arabic applications lacked features to help COVID-19 patients or the frontline hospital workers, while other world counties were more concerned about these individuals and developed applications to assist them during the pandemic.

Finally, the review shows that Arab countries did not consider the privacy issue, where the majority of the developed apps required users' personal information.

\section{References}

Abeler, J., Bäcker, M., Buermeyer, U., \& Zillessen, H. (2020). COVID-19 Contact Tracing and Data Protection Can Go Together. JMIR Mhealth Uhealth, 8(4:e19359). https://doi.org/10.2196/19359

Alfayez, Z. H. (2021). A review of mobile applications developed by academics for COVID19. International Journal of Advanced Technology and Engineering Exploration, 8(77), 529-536. https://doi.org/10.19101/IJATEE.2021.874058

Anonymous. (2020). Arab countries respond to COVID-19. Www.Arabstates.Undp.Org. https://www.arabstates.undp.org/content/rbas/en/home/coronavirus.html

Bassi, A., Arfin, S., John, O., \& Jha, V. (2020). An overview of mobile applications (apps) to support the coronavirus disease 2019 response in India. Indian Journal of Medical Research, 151(5), 468-473. https://doi.org/10.4103/ijmr.IJMR_1200_20

Cheng, W., \& Hao, C. (2020). Case-Initiated COVID-19 Contact Tracing Using Anonymous Notifications. JMIR Mhealth Uhealth, 8 (6 :e20369). https://doi.org/10.2196/20369

Hasan, H. F. (2021). Legal and Health Response to COVID-19 in the Arab Countries. Risk Management and Healthcare Policy, 14, 1141-1154. https://doi.org/https://doi.org/10.2147/RMHP.S297565

Hassounah, M., Raheel, H., \& Alhefzi, M. (2020). Digital Response During the COVID-19 Pandemic in Saudi Arabia. Journal of Medical Internet Research, 22(9). https://doi.org/10.2196/19338

HM Coastguard asks everyone to take extra care. (2020). Gov.Uk. https://www.gov.uk/government/\%0Apublications/coronavirus-action-plan

ISLAM, M. N., ISLAM, I., ISLAM, K. M. M., \& NAJMUL, A. K. M. (2020). A Review on the Mobile Applications Developed for COVID-19: An Exploratory Analysis. IEEE Access, 8. https://doi.org/10.1109/ACCESS.2020.3015102

Liberati, A., Altman, D. G., Tetzlaff, J., Mulrow, C., Gøtzsche, P. C., Ioannidis, J. P. A., Clarke, M., Devereaux, P. J., Kleijnen, J., \& Moher, D. (2009). The PRISMA Statement for Reporting Systematic Reviews and Meta-Analyses of Studies That Evaluate Health Care Interventions: Explanation and Elaboration. PLoS Medicine, 6(7).

Media, H. (2020). Roundup: Tech's role in tracking, testing, treating COVID-19. https://www.mobihealthnews.com/news/roundup-techs-role-tracking-testing-treatingcovid-19 
Najib, D. (2021). COVID-19 and the Arab World - Between a Rock and Hard Place. Science \& Diplomacy, 10(Special Issue). https://www.sciencediplomacy.org/article/2021/covid-19-and-arab-world-betweenrock-and-hard-place

Nayak, S., Blumenfeld, N. R., Laksanasopin, T., \& Sia, S. K. (2016). Point-of-Care Diagnostics: Recent Developments in a Connected Age. Analytical Chemistry, 89(1), 02-123. https://doi.org/10.1021/acs.analchem.6b04630

Salako, T., \& Huet, N. (2020). Coronavirus conundrum: COVID-19 tracking apps that don't breach privacy. https://www.euronews.com/2020/04/10/coronavirus-conundrumcovid-19-tracking-apps-that-don-t-breach-privacy

Singhal, T. (2020). A review of coronavirus disease-2019 (COVID-19). Indian Journal of Pediatrics, 87(4), 281-286. https://doi.org/10.1007/s12098-020-03263-6]

Turak, N. (2020). First Middle East cases of coronavirus confirmed in the UAE. Www.Cnbc.Com. https://www.cnbc.com/2020/01/29/first-middle-east-cases-ofcoronavirus-confirmed-in-the-uae.html

WHO Director-General's opening remarks at the media briefing on COVID-19. (2020). World Health Organization. https://www.who.int/dg/speeches/detail/who-director-general-sopening-remarks-at-the-media-briefing-on-covid-19---11-march-2020

Yasaka, T. M., Lehrich, B. M., \& Sahyouni, R. (2020). Peer-to-Peer Contact Tracing: Development of a Privacy-Preserving Smartphone App. JMIR Mhealth Uhealth, 8(4:e18936). https://doi.org/10.2196/18936 